\section{A One-Drop Cryoscope: The Tonicity of Frog and Goldfish Sera ${ }^{1}$}

A very promising device which provides objective register of freezing point depressions via recording potentiometer on relatively small samples $(0.05-0.1 \mathrm{ml})$ and an automatic nucleation feature to prevent undercooling, has recently been described ${ }^{2}$. This instrument, however, was not used with biological materials. This paper will describe its use with such materials and present a simple modification in the design of the sample chamber for samples of $0.02 \mathrm{ml}$

The modified sample chamber was essentially a glass tube with a thermistor sealed in its bottom. A glass tube (4 mm I.D. by $15 \mathrm{~mm}$ long) was one-third filled with liquid silicone rubber sealant (Dow Silastic 891) and allowed to harden. The thermistor probe (Glennite 32PB2) was prepared by grinding off most of its glass covering with a motorized fine stone. The thermistor leads were threaded through the bore of a short 18-gauge needle which was forced through the hardened sealant. The needle was removed and the probe pulled through the silicone rubber by its leads until the thermistor bead just reached the top of the sealant. A rubber grommet adapted the chamber to a larger diameter (7 mm I.D.) tube to provide a holder. Finally, leads and sample chamber were sealed in their holder with more sealant.

The design of the $20-\mu$ l chamber was shown to be valid by demonstrating that linearity obtained between concentration (in the biological range) and scale readings of the freezing points. A 100 mOsm concentration difference equalled 30 scale units on the recorder ${ }^{3}$ chart. It was further demonstrated that published values for the tonicity of a representative organism, Rana pipiens, may be reproduced with ease by use of the modified chamber.

Frogs, Rana pipiens, in apparent good health were obtained from a local supplier and kept in a laboratory tank containing a small amount of tap water (equivalent to

The tonicity of frog and goldfish sera, in equivalent osmolality and $\% \mathrm{NaCl}$

\begin{tabular}{|c|c|c|c|}
\hline \multirow[b]{2}{*}{ Animal } & \multirow[b]{2}{*}{$\begin{array}{l}\text { Number of } \\
\text { deter* } \\
\text { minations }\end{array}$} & \multicolumn{2}{|c|}{ Average Equivalent } \\
\hline & & $\begin{array}{l}\mathrm{KCl} \text { (mOsm) } \\
\pm \text { standard } \\
\text { error }\end{array}$ & $\begin{array}{l}\mathrm{NaCl} \% \\
\pm \text { confidence } \\
\text { interval }(95 \%)\end{array}$ \\
\hline Rana pipiens & 28 & $200 \pm 4.8$ & $0.65 \pm 0.05$ \\
\hline Crassius auratus & 11 & $289 \pm 4.3$ & $0.92 \pm 0.05$ \\
\hline
\end{tabular}

$20 \mathrm{mOsm} \mathrm{KCl}$ ) for four days at $23^{\circ} \mathrm{C}$ before bleeding. Blood was drawn directly from the ventricles and centrifuged under oil to pack the clot and cells and remove other potential nucleation centers. $20-\mu 1$ samples of the serum were run in the cryoscope and the results are presented in the Table. Frog serum has an average tonicity equivalent to $200 \mathrm{mOsm} \mathrm{KCl}$ or to $0.65 \pm 0.05 \%$ $\mathrm{NaCl}$. This value agrees with that obtained by $\mathrm{KroGH}^{4}$ and MACALLAM ${ }^{3}$. It is lower than that reported by HOBER ${ }^{6}$ and ADOLPH ${ }^{7}$. However, the former was derived from frogs held in a more concentrated environment than ours (equivalent to $57 \mathrm{mOsm} \mathrm{KCl}$ ) whereas the latter was an average synthesized from a number of species.

The equivalent tonicity for the serum of the goldfish Crassius auratus (L.), standard xanthic, common comet was also determined. The value obtained (Table) was equivalent to $289 \mathrm{mOsm} \mathrm{KCl}$ or to $0.92 \pm 0.05 \% \mathrm{NaCl}$. Although this value has not been previously reported, its correctness is substantiated by the following. The measurement falls in the general range of that reported for fresh-water teleosts 8 , and luxurious in vitro growth of goldfish tails occurs in the media used for human skin", whose tonicity falls in the $0.9 \% \mathrm{NaCl}$ range ${ }^{10}$.

Zusammenfassung. Es wird eine einfache Modifikation eines Kryoskopes zur objektiven Messung von Gefrierpunktserniedrigungen im Bereiche von $20 \mu 1$ beschrieben. Das Instrument eignet sich u.a. zur Bestimmung der Gefrierpunktserniedrigungen des Wirbeltierblutes.

\section{Levine and Diana A. Musallam}

Department of Biology, Wayne State University, Detroit (Michigan USA) and Friend's Boys' School, Ramallah (Jordan), January 20, 1964.

1 This work was supported by Grant $619 \mathrm{~A}$ from the Damon Rumyon Memorial Fund for Cancer Research, Publication No. 109 of the Department of Biology, Wayne State University.

2 C. Lucarain, Rev. franç. Clin. Biol. 7, 213 (1962).

${ }^{3}$ Sargent, MR, 2.5 MV full scale, 2 inches per min.

4 A. KROGH, Osmotic Regulation in Aquatic Animals (Cambridge Univ. Press, 1939), p. 155.

ta. Macallam, Phys, Rev, 6, 316 (1926).

- R. Hober, Physical Chemistry of Cells and Tissues (Blakiston Co., Philadelphia 1948), p. 587.

7 E. Anotplt, J. exp. Biol. 49, 319 (1927)

8 W. S. HoAr et al. Some Aspects of the Physiology of Fish (Publications of Ontario Fisheries Research Laboratory, No. LXXI, Univ, of Toronto, Biol. Ser. No. 59); R. HoвER, Physical Chemistry of Cells and Tissues (Blakiston Co., Philadelphia 1948), p. 584.

$8 \mathrm{~F}, \mathrm{Hu}$ and W. Chavin, J. Invest. Dermatol. 34, 377 (1960).

$10 \mathrm{Im}$ indebted to Dr. W. G. Herm for his generous help in con* structing the Wheatstone bridge, to Messrs. Lee Peterson for building the apparatus and J. Young for the goldfish serum.

\section{Rice Blast, Nyctotemperature, and Nitrate Reductase}

That a particular genotype-nyctotemperature combination is an essential prerequisite for the occurrence of 'blast' disease of rice (Oryza sativa L.) caused by Piricularia oryzae Cav. has already been shown in this laborator $\mathrm{y}^{1}$. Subjecting susceptible rice plants (CO 13) to a nyctotemperature regime of $20^{\circ} \mathrm{C}$ gave the necessary predisposition for successful infection by the 'blast' fungus and in such plants there was an accelerated tempo of nitrogen metabolism with a considerable synthesis of the amide glutamine 2 . Conversely, when susceptible plants

${ }^{1}$ S. Suryanarayanan, Proc. nat. Inst. Sci. India 24 B, 285 (1958). 2 S. Survanarayanan, Curr. Sci. $2 \%, 447$ (1958). 